\title{
Blood Serum Minerals - in vivo Mineral Interactions Following Iron Overload
}

\author{
MIRELA AHMADI ${ }^{2}$, IOAN PET ${ }^{2 *}$, LAVINIA STEF ${ }^{1}$, GABI DUMITRESCU ${ }^{1}$, SILVIA PATRUICA ${ }^{1}$, MARIOARA NICULA ${ }^{1}$, \\ LILIANA PETCULESCU CIOCHINA ${ }^{1}$, MIHAELA POPA ${ }^{3}$, DOREL DRONCA ${ }^{1 *}$ \\ "Faculty of Veterinary Medicine, Banat's University of Agricultural Sciences and Veterinary Medicine „King Michael I of Romania” \\ from Timisoara - USAMVB, 119 Calea Aradului, 300645, Timisoara, Romania \\ 'Faculty of Bioengineering of Animal Production, Banat's University of Agricultural Sciences and Veterinary Medicine "King \\ Michael I of Romania from Timisoara -USAMVB, 119 Calea Aradului, 300645, Timisoara, Romania \\ ${ }^{3}$ Faculty of Engineering of Hunedoara, Polytechnic University of Timisoara
}

Iron is an essential mineral for the human, animal and plant kingdom, being present in water, soil and air. In the organism, iron is found both as a ferrous ion $\left(\mathrm{Fe}^{2+}\right)$ and as a ferric ion $\left(\mathrm{Fe}^{3+}\right)$, being involved in oxidoreduction processes and as part of protein structure or in complexes with anions present in cells and tissues. The optimal iron concentration in the body depends on several characteristics (organism type, age, gender, environmental conditions - especially related to altitude, physiological status and others), but there is a rather small variation between the minimum and maximum required concentration -deficiency or excess having a detrimental effect on the organism. In the present work iron gluconate hydrate $\left(10 \mathrm{mg} \mathrm{Fe} \mathrm{e}^{2+} / \mathrm{kg}\right.$ body) has been administered intraperitoneally to rabbits, in two separate injections. We formulated a diet rich in plants with protective role, and at the end of the experiment the level of blood serum sodium, potassium, magnesium, ionic calcium, total calcium, iron and chlorine was measured. The results showed that iron overload led to a significant increase of potassium (55.74\%), magnesium (31.57\%), iron (20.86\%) and calcium (with $19.69 \%$ total $\mathrm{Ca}$ and $17.19 \%$ ionic $\mathrm{Ca}$ ), while the concentration of sodium and chlorine showed non-significant decreases (sodium decreased by 3.83\%, and chlorine decreased by $1.58 \%$ ). Therefore, the excess iron administered over a short period of time to rabbits influences the metabolism of several minerals such as potassium, magnesium, calcium, iron as well as sodium and chlorine and that is reflected in their blood serum level.

Keywords: iron overload, blood serum minerals, rabbits

Iron is a widespread element present in nature and living organisms, essential for all forms of life. It occurs in different amounts and chemical forms in water, soil and air. In living organisms iron homeostasis is mediated by specific genes and proteins [1]. Iron is part of heme proteins (metalloproteins), non-heme proteins and iron-sulfur proteins. Hemeproteins are proteins with a heme as prosthetic group, bound to the protein by covalent or noncovalent bonds. These proteins have specific functions such as those involved in oxygen reduction, oxygen carrying, and electron transfer (in oxidative phosphorylation) [2]. The heme contains iron as $\mathrm{Fe}^{2+}$ or $\mathrm{Fe}^{3+}$, which plays very important role in the hemeprotein activity and function. The iron of hemeprotein plays a crucial role in binding of oxygen (hemoglobin and myoglobin carry oxygen), nitric oxide, carbon monoxide or hydrogen sulfide, processes that modulate signal transduction. All these indicate that iron is an essential mineral for living organisms, butitshould only be present in certain amounts. Iron homeostasis involves three main processes chiefly, uptake, storage and removal. The metabolism of iron at intracellular level is mediated by several specialized proteins and genes [1,3] .

Synergistic and antagonistic functions are very important in living organisms, especially when administration of pharmaceutical or higher doses of compounds such as drugs and micronutrients is involved. Both metal deficiency and overload can result in abnormal cellular function or damage. Interactions between metal ions such as iron and copper were described long ago but the molecular mechanisms governing these interactions are still poorly understood. Studies in mammals showed that copper levels increase in the intestinal mucosa, liver and blood during iron deficiency. Looking at iron-copper interaction in a rat model experiment $\mathrm{Ha}$ et al. found that high iron intake impairs growth and causes systemic copper deficiency while higher copper intake influences iron-overload phenotype [4]. Recent evidence from this laboratory showed antagonistic or synergistic action between minerals in animal model experiments [3, 5-9]. Also, the experiments show variations in the response of the effectors or inhibitors regarding the evolution, the toxicity effect, the reproduction, the quality of meat, milk, eggs and others animal products [10-13].

In the present paper we evaluate the effect of iron overload for a short period of time in relation to serum potassium, magnesium, calcium, chlorine, and sodium levels.

\section{Experimental part}

Materials and methods

We tested the effect of iron overload on the status of several minerals in rabbit serum. We chose iron overload because in the Timis County (Romania) there are areas where the soil and groundwater are overloaded with iron and manganese. Our experiment was conducted during the summer time on German Lop Eared rabbits, divided into two groups: the control group $-C$, and the experimental group $-\mathrm{E}$, with $703 \mathrm{~g}$ as mean weight for each rabbit. There was an acclimation period for the rabbits before the experiment was started. The experiment lasted 43 consecutive days. During the experiment adequate ventilation was provided and all the experimental

\footnotetext{
* email: ioan.petz@yahoo.com,ddronca@animalsci-tm.ro
} 
conditions followed the rules governing animal welfare $[14,15]$. The experimental protocol consisted in administration of ferrous-gluconate hydrate (provided by Flika company) as $10 \mathrm{mg} \mathrm{Fe}{ }^{2+} / \mathrm{kg}$ body weight via intraperitoneal injection for the experimental group (E), two times during the experiment. The control group (C) received physiological serum. The experimental group received a special diet consisting of fresh organic leaves, seeds and vegetables that provided a very good antioxidant activity. The feed included clover, radish, rucola, parsley, leek, fenugreek, coriander, chives, cucumber, carrots and black cumin seeds. At the end of experiment biochemical blood tests were performed in order to determine the concentration of potassium, magnesium, calcium, iron, chlorine, and sodium in serum. The blood work was carried out in an accredited biochemistry laboratory. The data were statistically processed as average and standard deviation values and displayed in graphical form.

\section{Results and discussions}

Serum potassium, magnesium, total and ionic calcium concentration in blood serum are shown in figure 1.

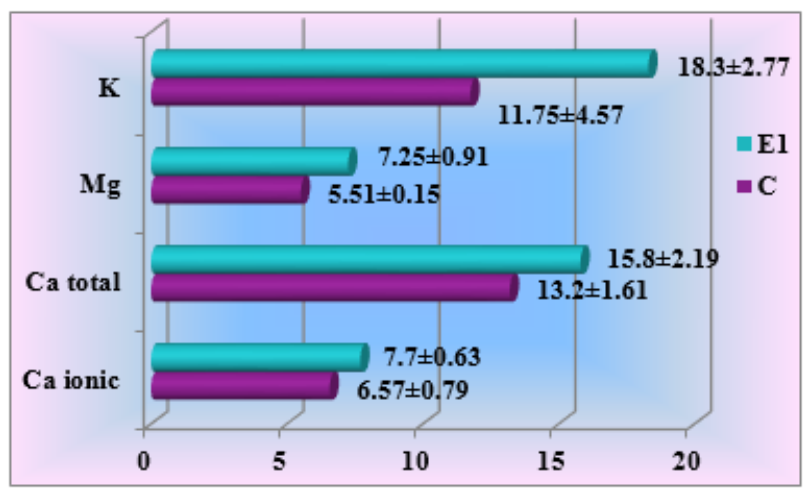

Fig. 1. Serum concentration of calcium, magnesium and potassium in rabbits after iron overload $[\mathrm{mg} / \mathrm{dL}]$

Our experiment showed that iron overload for a short period of time increases potassium, magnesium and calcium concentration in serum. Thus, serum potassium increased from $11.75 \mathrm{mg} / \mathrm{dL}$ to $18.30 \mathrm{mg} / \mathrm{dL}$ in experimental rabbits compared to control group after administration of iron, even though the diet contained plants with role in protection against metal overload.

Magnesium concentration also increased after iron overload from $5.51 \mathrm{mg} / \mathrm{dL}$ to $7.25 \mathrm{mg} / \mathrm{dL}$, but the increase was more moderate compared to serum potassium. Blood iron is positively associated with magnesium and iron intake and this is in agreement with the results reported by Zumin and his associates in 2008 [16].

As for calcium, the concentration of total calcium and ionic calcium in blood serum underwent a slight increase compared to the control group after the administration of iron in concentrations higher that the physiological values. Thus, the total calcium increased from $13.20 \mathrm{mg} / \mathrm{dL}$ to $15.80 \mathrm{mg} / \mathrm{dL}$ and the ionic calcium increased from $6.57 \mathrm{mg} /$ $\mathrm{dL}$ to $7.70 \mathrm{mg} / \mathrm{dL}$ compared to the values determined in rabbits from the control group. Calcium is found in the tissues in different forms such as ionized calcium -about $50 \%$, calcium bound to proteins (like albumin, and globulins) - about $40 \%$, or calcium bound to anions -about $10 \%$. The ionized calcium is the most active form and is known as free calcium. In the clinical laboratories it is used for the accurate estimation of total calcium, taking into account the concentration of serum albumin [17].

Potassium is the main intracellular cation, as more than ninety-eight percent of total potassium is found in intracellular fluids. Together with calcium and magnesium, potassium is involved in heart and skeletal contraction, glomerulo-tubular renal function and nerve activity, so increased serum concentration of these three cations could have severe consequences [18].

Figure 2 and figure 3 present the serum concentrations of sodium and chlorine in rabbits after iron overload for a short period of time.

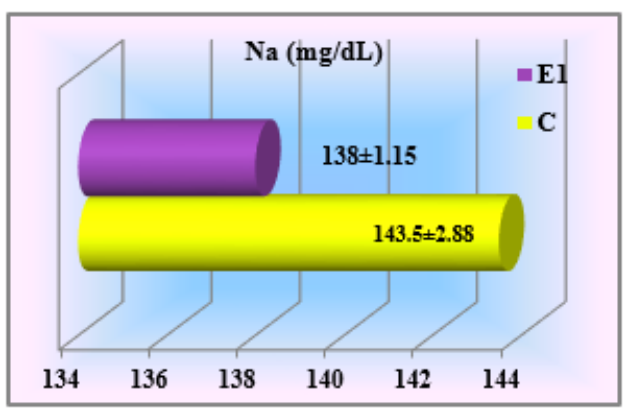

Fig. 2. Sodium level in rabbits serum

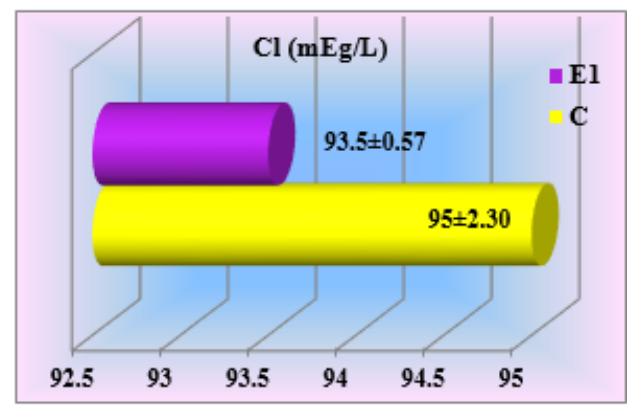

Fig. 3. Serum chlorine level in rabbits

Sodium and chlorine concentration in rabbit serum slightly decreased in experimental group compare to control group (with 3.83\% for $\mathrm{Na}$ and $1.58 \%$ for $\mathrm{Cl}$ ) after administration of iron. Chlorine is an anion that can occur in the saltform of ferric chloride in the presence of iron and hydrochloric acid found in large amount in the stomach gastric juice.

The enzyme responsible for potassium and sodium regulation is ATPase, which maintains $\mathrm{K}$ and $\mathrm{Na}$ concentration across cell membrane and could be activated or inhibited by low or high concentrations of iron. Hyperkalemia can be augmented by moving the potassium out of the cel; by acidaemia, a process that carries hydrogen ions into the cells. Therefore, iron overload negatively affects ATPase activity, which is responsible for potassium regulation and that may explain the potassium increased level in serum after iron overload. Moreover, increased iron concentration accompanied by increased potassium, magnesium and calcium levels affect intraand extracellular activity, leading to oxidative stress and systemic inflammation [19].

Diets rich in plants with antioxidant activity modulate the effect of excess iron in various tissues due to the presence of bioactive ligands with effect on iron chelation and limiting its bioavailability. It has been shown that a mixture of curcumin, quercetin and gallic acid potentiated the toxic effect of iron overload in experimental animals by a tris-bidentate coordination complex of curcuminquercetin-gallic acid-Fe(III) [20].

Although iron is essential for many proteins and enzymes, in excess it acts as a toxic agent due to its involvement in the Fenton reaction leading to oxidative stress and disrupting most of the metabolic pathways, with changes in the serum concentration of other minerals. Figure 4 presents the variations of iron concentration in blood serum after iron overload. 


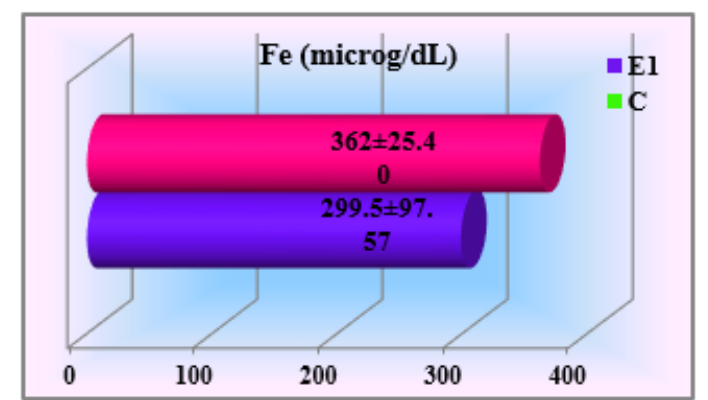

Fig. 4. Concentration of serum iron, chloride and sodium after iron administration to rabbits

Serum iron increased from $299.5 \mu \mathrm{g} / \mathrm{dL}$ to $362 \mu \mathrm{g} / \mathrm{dL}$ after iron overload. Compared to the other minerals in this experiment, even though iron increased by about $20 \%$ in the experimental group, it was not the highest value recorded. The highestincrease was recorded for potassium (more than 55\%, followed by magnesium, about 31\%).

Hepcidin plays a very important role in iron homeostasis, being a key regulatory protein for humans and mammals. In certain medical conditions when the level of hepcidin is high (such as inflammation), the absorption of iron at gut level decreases due to iron trapping within hepatocytes and macrophages, so the development and maturation of red blood cells is impaired due to unavailable iron, which inevitably leads to anemia. Conversely, when hepcidin level drops to abnormally low concentrations (such as in hemochromatosis), the ferroportin removes the iron from intracellular stores, increases the iron absorption in the gut and that results in iron overload [21].

The iron in the diet is absorbed through the duodenal mucosa, where specific proteins are involved in the transport of non-heme iron through the apical and basolateral membrane of the duodenal epithelial cells. The main protein responsible for ferric ion $\left(\mathrm{Fe}^{3+}\right)$ intake from the diet is the DMT1 -divalent metal transporter 1 - , which is active after the ascorbate ferrireductase enzyme (Dcytb) reduces insoluble ferric ion $\left(\mathrm{Fe}^{3+}\right)$ from the diet to ferrous ion $\left(\mathrm{Fe}^{2+}\right)$. Solubility of iron is crucial to living organisms; thus, inside the cells there are three ways to increase iron solubility: reduction, chelation, and acidification, where the ascorbate has a very important role [22].

Also, the extracellular iron is a very important mineral for the energy metabolism, being taken up inside the cells, transported to mitochondria in order to be used in ATP synthesis, DNA metabolism and other processes. Blood ferric iron is bound to protein transferrin, while diferrictransferrin is bound to transferrin receptors on the plasma membrane. Due to a decrease in $\mathrm{pH}$ within the endosome the complex of iron-protein becomes dissociated, the transferrin and diferric-transferrin are recycled and the ferric ion $\left(\mathrm{Fe}^{3+}\right)$ is reduced to ferrous ion $\left(\mathrm{Fe}^{2+}\right)$ by a reductase. From the endosome the divalent metal transporter 1 (DIT1) carries the iron to the cytoplasm where it is found as a metabolically active iron - known as labile iron pool. This metabolically active iron is used in DNA metabolism (such as synthesis, repair, cell cycling), and the excess is stored as ferritin forming a hetero-polymer of heavy and light ferritin chains or is taken out of the cell as ferroportin [23].

The posttranscriptional regulatory mechanism tightly mediates the cellular iron homeostasis by target mRNAs, involving two iron regulatory proteins -IRP1 and IRP2, and also by iron responsive elements -IRE. Iron by itself is the mainly regulatory factor for IRPs inside the cells -low concentrations of intracellular iron suppress the translation of proteins (such as FTH1, FTL, FPN) -proteins that are responsible for iron storage and export. Conversely, high concentration of intracellular iron stabilizes the TFR1 proteins involved in iron uptake [24].

The most common diseases caused by iron deficiency are considered nutritional disorders, while the hemochromatosis - considered genetic disorder -is the most common disease caused by iron excess, and iron overload following therapeutic transfusions or iron supplementation for a considerable period of time $[2,20$, 21, 25-28].

\section{Conclusions}

Serum minerals are very important for health status evaluation, calcium, magnesium, sodium and potassium being involved in muscle contraction, in kidney and cardiac function and also in blood pressure, while iron as part of hemoglobin, is the main carrier of oxygen to the cells.

Our results presented significantly increased concentrations in the experimental group compared to control group, potassium -by $55.74 \%$, magnesium -by $31.57 \%$, iron -by $20.86 \%$, total calcium -by $19.69 \%$ and ionic calcium -by $17.19 \%$ after iron overload (as ferrousgluconate hydrate).

Concentration of chlorine and sodium did not show significant variations after iron administration - sodium decreased by $3.83 \%$ and chlorine decreased by $1.58 \%$ in the experimental group compared to control group.

The results of this study suggest that iron overload influences the metabolism of several minerals such as potassium, magnesium, calcium, iron as well as sodium and chlorine and that is reflected in their blood serum level.

\section{References}

1.CAIRO, G., BERNUZZI, F., RECALCATI, S., Genes \& Nutrition, 2006, 1, no 1 , pp. 25.

2.CONWAY, D., HENDERSON, M.A., Anaesthesia and Intensive Care Medicine, 2019, 20, 3, pp. 175.

3.AHMADI, M., NICULA, M., DUMITRESCU, G., STEF, L., PET, I., PETCULESCU CIOCHINA, L., DRONCA, D., Rev. Chim. (Bucharest), 69, no. 10,2018, p. 2731.

4.HA, J.H., DOQUER, C., WANG, X., FLORES, S.R., COLLINS, J.F. PloS One, 2016, 11, (8), e0161033.

5.PUP, M., AHMADI, M., OLARIU, L., PREJ BEANU, R., VERMESAN, H., Rev. Chim. (Bucharest), 59, no. 4, 2008, p. 405.

6.VERMESAN, H., PUP, M., AHMADI, M., VERMESAN, D., PREJ BEANU, R., Rev. Chim. (Bucharest), 59, no. 8, 2008, p. 891.

7.NICULA, M., PACALA, N., STEF, L., PET, I., IANCU, T., DRONCA, D., AHMADI, M., GHERBON, A., DELEANU, B., Rev. Chim. (Bucharest), 68, no. 8, 2017, p. 1807.

8.NICULA, M., PACALA, N., RADULOV, I., AHMADI, M., DRONCA, D., GHERBON, A., Rev. Chim. (Bucharest), 68, no. 9, 2017, p. 2006.

9.NICULA, M., PACALA, N., STEF, L., PET, I., DRONCA, D., GHERBON, A., AHMADI, M., Rev. Chim. (Bucharest), 68, no. 12, 2017, p. 2747

10. DRONCA, D., PACALA, N., BURA, M., TELEA, A., VINTILA, T., Bulletin of the Univ. Agr. Sci. Med. Vet. - Animal Husbandry and Biotechnologies, 2005, 61, p. 387

11.DRONCA, D., PACALA, N., OROIAN, T., TELEA, A., VINTILA, T., PET, I., Bulletin of the Univ. Agr. Sci. Med. Vet. - Animal Husbandry and Biotechnologies, 2006, 62, 2006, p. 209

12.PACALA, N., BENCSIK, I., DRONCA, D., PETROMAN, I., PETROMAN, C., CEAN, A., CARABA, V., BOLEMAN, A., J. Food Agr. Environ., 2011, 9, no 1, p. 219.

13.DUMITRESCU, G., PET, I., DRONCA, D., AHMADI, M., PETCULESCUCIOCHINA, L., FILIMON, N.M., POPESCU, R., Rev. Chim. (Bucharest), 69, no. 1, 2018, p. 140.

14.*** Romanian Law nr 205/2004 (Art. 7, 8, 22), publ. in M.O. of Romania, Partl, Nr. 531/14.06.200 
15.*** Directive 2010/63/EU of the European Parliament and of the Council of 22 September 2010 for Protection of Animals Used for Experimental and Other Scientific Purposes

16.ZUMIN, S., XIAOQUN, P, Diabetes care, 2008, 31, no. 4, e25.

17.HIGGINS, C., Ionized calcium, July 2007, https://acutecaretesting.org/ en/articles/ionized-calcium.

18.PARIKH, M., WEBB, S.T., Continuing Education in Anaesthesia Critical Care and Pain, 2012, 12, no. 4, p.195.

19.AHMADI, M., DELEANU, B., OSTAN, M., STANCU, M., DRONCA, D. SCURTU, M., CRETESCU, I., Rev. Chim. (Bucharest), 67, no. 10, 2016, p. 2015.

20.CHANNARAYAPPA, K.N.L., VENKATARANGANNA, M., GOWTHAM, R.G., PATIL, H., DAVE, H., J ournal of Trace Elements in Medicine and Biology, 2018, 45, no. 1, p. 114.

21.GINZBURG, Y.Z., VINCHI, F., Chapter 72 -Iron Overload, in Transfusion Medicine and Hemostasis -Clinical and Laboratory Aspects, $3^{\text {rd }}$ edition, 2019, pp. 433-436.
22.GINZBURG, Y.Z., Chapter 2: Hepcidin-ferroportin axis in health and disease, in Vitamins and Hormones (LITWACK, G. -Editor), Elsevier Inc., 2019, 110, pp. 264.

23.BIBBIN, T.P., MANZ, D.H., TORTI, F.M., TORTI, S.V., ExpertRev. Hematol., 2017, 10, no. 1, p. 65.

24.TORTI, S.V., TORTI, F.M., Nat. Rev. Cancer, 2013, 13, no. 5, p. 342.

25.PERCY, L., MANSOUR, D., FRASER, I., Best Practice and Research Clinical Obstretics and Gynaecology, 2017, 40, p. 55.

26.POWERS, J.M., BUCHANAN, G.R., Hematology, Oncology Clinics of North America, 2019, 33, no. 3, p. 393.

27.SHAZ, B.H., HILLYER, C.D., GIL M.R., Chapter 72 - Iron Overload, in Transfusion Medicine and Hemostasis - Clinical and Laboratory Aspects, $3^{\text {rd }}$ ed., Elsevier, 2019, p. 433-436.

28.ZHANG, H., ZHABYEYEV, P., WANG, S., OUDIT, Y., Biochimica et Biophysica Acta - Molecular Basis of Disease, 2019, 1865, no. 7, p. 1925.

Manuscript received: 14.10 .2019 